\title{
UMA ANÁLISE SISTÊMICO-FUNCIONAL DO DIZER EM ARTIGOS CIENTÍFICOS DE GRADUANDOS
}

\author{
(A systemic functional analysis of Dizer (say) \\ in papers by B.A. students)
}

\author{
Medianeira SouZA \\ (Universidade Federal de Pernambuco/UFPE) \\ Wellington Vieira MENDES \\ (Universidade do Estado do Rio Grande do Norte/UERN)
}

\begin{abstract}
Resumo: Os processos verbais são o foco de nossa análise para investigar a forma como o dizer é construído em artigos acadêmicos produzidos por alunos de Letras, compreendendo que a representação do dizer se faz por meio desses processos, os quais materializam "vozes" que corroboram opiniões, ideias e pensamentos, ao introduzirem o discurso direto e indireto. Propomo-nos, então, a averiguar, à luz da Linguística Sistêmico-Funcional, como os graduandos em Letras se apropriam deste tipo de processo para construírem seus artigos.

Palavras-chave: Transitividade, processos verbais, artigos acadêmicos.
\end{abstract}

Abstract: Verbal processes are the focus of our analysis, which aims at investigating how the act of saying is built up in academic papers by students of Languages and Literature, bearing in mind that the representation of saying is carried by these processes, which materialize "voices" that introduce opinions, ideas and thoughts, in direct and indirect speech. Therefore we aim at investigating, following the principles of Systemic Functional Linguistics, how those students approach this kind of process to build their articles.

Key-words: Transitivity, verbal processes, academic articles.

\section{INTRODUÇão}

Uma análise sistêmico-funcional realiza-se em situações de uso efetivo da língua e, neste trabalho, dado o interesse de averiguar questões relativas à elaboração do dizer através da categoria léxico-gramatical da transitividade, os processos verbais são o foco de nossa análise. O sistema de transitividade é composto, segundo Halliday e Matthiessen (2004), por 
seis tipos de processos: materiais, mentais, relacionais, comportamentais, verbais e existenciais. Privilegiamos, neste trabalho, os processos verbais com vistas a investigar como o dizer é construído em artigos acadêmicos produzidos por alunos de Letras. Entendemos que a representação do dizer constrói-se por meio desses processos, os quais materializam vozes externas, ou mesmo internas ao texto, que introduzem ou corroboram teses, ideias e pensamentos.

Com esta investigação, propomo-nos, também, a averiguar, à luz da Linguística Sistêmico-Funcional (LSF), como os graduandos em Letras se apropriam desse recurso argumentativo na escritura de seus artigos. Assim sendo, como recorte teórico-metodológico, detemo-nos ao funcionamento dos processos verbais "dizer", "afirmar", "mostrar" e "falar" e seus participantes obrigatórios - Dizente, Verbiagem e seu participante opcional - Receptor, caso este ocorra - em artigos acadêmicos escritos e publicados por alunos da graduação em Letras de todo o Brasil. Nossos dados são um recorte de dois corpora: da revista Ao pé da letra, do Departamento de Letras da Universidade Federal de Pernambuco/UFPE (Cf. Souza, 2011) e de anais de eventos científicos do Campus Avançado Prof. ${ }^{a}$ Maria Elisa de Albuquerque Maia, da Universidade do Estado do Rio Grande do Norte (CAMEAM/UERN), em Pau dos Ferros/RN, realizados nos últimos três anos (Cf. Mendes, 2011). Das publicações da Ao pé da letra, selecionamos vinte artigos do volume I e dos anais de eventos foram selecionados também vinte artigos da VII Semana de Estudos Linguísticos e Literários de Pau dos Ferros (SELLP).

O primeiro procedimento metodológico adotado foi a criação de um arquivo eletrônico com todos os artigos publicados na revista $A$ opé da letra durante seus dez anos de existência. Esse arquivo armazenado em mídias eletrônicas (pen drives, cd-roms) é constituído, portanto, dos artigos acadêmicos disponibilizados, por volume, no website da revista: www.revistaaopedaletra. net, os quais, após arquivados, foram convertidos do formato $p d f$ (Adobe Reader) para o formato txt, extensão necessária à aplicação do software Word Smith Tools (SARDINHA, 2009), ferramenta utilizada pelos pesquisadores da LSF e da Linguística de Corpus para seleção de dados. Organizado o arquivo, a aplicação do software identificou os processos verbais "dizer", "afirmar", "mostrar" e "falar", escolhidos para esta análise, a qual se insere em uma pesquisa de caráter mais amplo que investigará os processos verbais mais recorrentes em toda a década de publicação do periódico $A o p e ́$ da 
letra e de anais de eventos científicos do CAMEAM/UERN, do período de 2008 a 2010. É importante acrescentar que estas empreitadas, por sua vez, integram uma rede maior de pesquisa denominada Systemics Across Languages Research Network (SAL), que, na América Latina, é coordenada pela Profa. Leila Barbara (PUC-SP/LAEL/CNPq) e, em âmbito internacional geral, pelo Prof. Christian Matthiessen, da Polytecnic University of Hong Kong.

Definidos os processos e o total de artigos, recolhemos as cento e noventa e cinco orações constituídas por tais processos, para procedermos à análise, sem deixar de observar o entorno oracional e o contexto de uso, elementos relevantes na construção da significação e consequente interpretação do texto. Em seguida, analisamos a instanciação sintática das orações, observando os grupos nominais, pronominais ou oracionais realizadores dos participantes Dizente e Verbiagem e a apresentação do processo.

Feitos estes esclarecimentos de teor contextual, no que diz respeito a objetivos, escolhas e procedimentos metodológicos, passamos a situar o leitor em relação ao aporte teórico que respalda nossa pesquisa. Na segunda parte do artigo, apresentamos análise de orações organizadas com os processos verbais "dizer" "dizer", "afirmar", "mostrar" e "falar". Cremos que esse painel resumitivo é suficiente, não somente para demonstrar o processo analítico efetivado, como para revelar a natureza da interpretação em uma análise sistêmico-funcional, nos moldes delimitados para este trabalho.

\section{NoçÕES TEÓRICAS BÁSICAS}

Apresentamos nesta seção comentários de caráter introdutório a respeito da teoria que sustenta a análise aqui empreendida - a LSF e seu sistema de transitividade. Compreender usos linguísticos específicos, neste caso, a função dos processos verbais e de seus participantes em relação ao modo de citar e de construir argumentos a partir dessas citações, implica avançar no entendimento da constituição gramatical do gênero em questão, ao mesmo tempo em que possibilita uma compreensão mais complexa das escolhas léxico-gramaticais realizadas pelos discentes-autores com vistas à construção do significado pretendido em seus artigos. 


\subsection{A LSF, o sistema de transitividade e os processos verbais}

Para a LSF, a linguagem se organiza mediante a inter-relação de três funções que constituem os propósitos principais da linguagem (Halliday, 1985). São as chamadas metafunções da linguagem: a ideacional, a interpessoal e a textual. A metafunção ideacional representa, ou constrói, os significados de nossa experiência do mundo exterior ou interior por meio do sistema de transitividade. A interpessoal expressa as interações e os papéis assumidos pelos usuários, revelando as atitudes destes para com o interlocutor e para com o tema abordado por meio do sistema de modo e modalidade. A metafunção textual está ligada ao fluxo de informação e organiza a textualização por meio do sistema de tema e coesão. Nessas três metafunções, a oração, unidade básica para análise léxico-gramatical, é a realização simultânea de três significados: uma representação (significado no sentido de conteúdo); uma troca (significado como forma de ação); e uma mensagem (significado como relevância para o contexto).

De acordo com a LSF, os elementos linguísticos não significam isoladamente: o significado é codificado em um enunciado como um todo integrado e os significados são alcançados por meio de escolhas que os falantes fazem frente às escolhas que poderiam ter sido feitas. Uma gramática funcional destina-se, pois, a revelar, pelo estudo das sequências linguísticas, os significados que estão codificados por essas sequências. Para essa abordagem teórica, cada oração instancia três significados simultaneamente, os quais estão relacionados às metafunções da linguagem já mencionadas.

Halliday (1985) define a linguagem como um sistema semiótico social, entre os sistemas de significado que compõem a cultura humana. Esse fato permite afirmar que a linguagem, o texto e o contexto, juntos, são responsáveis pela organização e desenvolvimento da experiência humana. Estudam-se, então, as formas léxico-gramaticais, como a transitividade em relação a suas funções sociais. O sistema de transitividade é, então, entendido como a categoria gramatical, relacionada ao componente ideacional da LSF, responsável pela representação das ideias, da experiência humana, isto é, experiências do mundo real, inclusive do interior da consciência.

A transitividade é, portanto, a base da organização semântica da experiência, um conjunto de tipos oracionais com diferentes transitividades, instanciando experiências distintas. Conforme descrita na LSF, a transitivi- 
dade possibilita identificar as ações e atividades humanas que estão sendo expressas no discurso e que realidade está sendo retratada. Essa identificação se dá por meio dos principais papéis de transitividade: processos, participantes, e circunstâncias e permite analisar quem faz o quê, a quem e em que circunstâncias.

Cada tipo de processo - material, relacional, mental, verbal, comportamental e existencial - estabelece o seu próprio esquema de construir um domínio particular da experiência. Dessa forma, o sistema de transitividade busca representar as experiências externas e internas que vivenciamos no mundo que nos rodeia e no mundo de nossa consciência, além de configurar também o mundo abstrato das relações de classificar e identificar (Halliday \& Matthiessen, 2004). A Figura 01 - Processos do Sistema de Transitividade da $L S F$, a seguir, apresenta os processos constitutivos deste sistema e sua significação. A sua representação em círculo reflete o caráter contínuo da classificação, a qual só pode ser estabelecida nos contextos de uso efetivo desses processos em combinação com participantes e circunstâncias a eles relacionados.

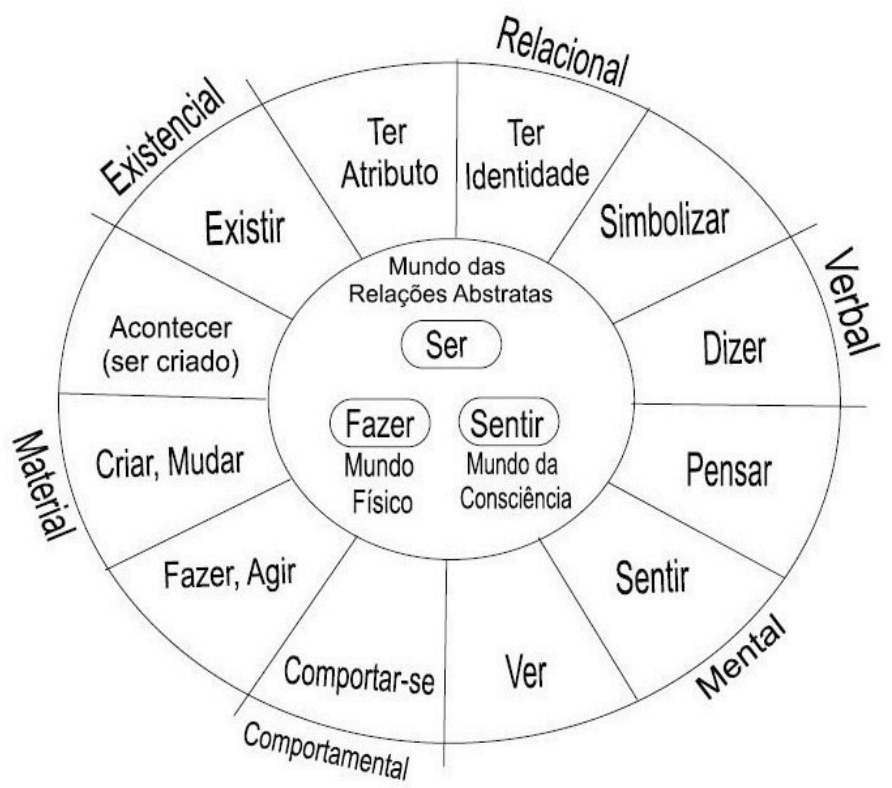

Figura 1: Processos do Sistema de Transitividade da LSF Fonte: Halliday \& Matthiessen, 2004, p. 172 (adaptada). 
Na representação dos conteúdos vivenciados pelos atores sociais e configurados através do sistema de transitividade, três tipos de processos são tidos como principais e três como secundários: os materiais, os mentais, os relacionais e os comportamentais, os verbais, os existenciais, respectivamente. A natureza da compreensão que pretendemos atingir com esta análise nos faz eleger os processos verbais como foco de reflexão para alcançar nosso propósito: compreender como o dizer é construído nos artigos acadêmicos produzidos por alunos da graduação em Letras, de universidades brasileiras, aqui representados por artigos publicados em período especializado e em anais de congressos.

\subsection{Os processos verbais em evidência}

Para apresentar os processos verbais, utilizamos algumas amostras do próprio corpus de análise, especificamente dos textos da Revista Ao pé da letra. Para a retomada da origem dos exemplos, entre parênteses, indicamos o volume do período, o artigo de onde a amostra foi destacada e a página no corpus. Passemos, então, a demonstração dos processos em pauta.

Processos verbais são aqueles que expressam formas de dizer; ou constroem o dizer. São, portanto, os processos do comunicar, do dizer, do indicar. Um processo verbal típico tem como participantes inerentes um Dizente, que diz ou comunica algo, como o participante grifado na oração: "Isso nos leva a afirmar que mesmo sendo transmitido oralmente, o telejornal é um texto primariamente escrito". (Vol. I, art. III, p. 36). Esse participante pode ser consciente ou não, como acontece com o processo "apontar", no exemplo "Essas relações quantitativas nos apontam algumas considerações relevantes para a investigação da natureza e do comportamento dessas estratégias no texto noticioso falado." (Vol. I, art. III, p. 33).

O participante Verbiagem e/ou Locução refere-se àquilo que é dito, comunicado ou apontado, o qual geralmente é realizado por um grupo nominal e/ou oração, respectivamente, conforme grifado no exemplo: "No caso do gênero aqui tratado, podemos falar numa "mescla" dos estilos falados e escritos". (Vol. I, art. III, pag.: 35). O que é dito pode também ser codificado em uma oração projetada, chamada de locução, a qual completa a significação do processo verbal. A oração, a seguir, ilustra o que afirmamos: "Isso nos leva a afirmar que mesmo sendo transmitido oralmente, o 
telejornal é um texto primariamente escrito." (Vol. I, art. III, p. 36). Pode haver ainda um terceiro e opcional participante chamado de Receptor, que é aquele para quem o processo é dirigido. Vale ressaltar mais uma vez que na LSF, o dizer tem um sentido mais amplo, incluindo qualquer intercâmbio simbólico de significados como assinalar, mostrar, apontar etc (Cf. Ghio; Fernández, 2008).

Em análises de narrativas orais, Halliday e Matthiessen (2004) afirmam que esse tipo de processo contribui para a criação da narrativa porque torna possível estabelecer passagens dialógicas em narrativas escritas e desenvolver relatos de diálogos em narrativas orais. Assim, processos verbais podem apresentar como Verbiagem o discurso direto ou o discurso indireto. Nossos dados de artigos acadêmicos apresentam casos de discurso direto e indireto(paratático e hipotático, respectivamente, na terminologia sistêmica), embora, de acordo com a natureza do gênero em estudo, a introdução desses discursos cumpra propósitos outros, que não os das narrativas orais, isto porque a citação é vista como prática intertextual que coloca em discussão a experiência científica acumulada, e também porque pode fornecer justificativas para argumentos e demonstrar a novidade de uma posição (Hoffnagel, 2009). Isto é o que demonstramos a seguir, ao interpretar o funcionamento dos processos verbais no artigo acadêmico, de modo a oferecer uma análise deste processo em um gênero escrito da esfera científica.

\section{O USO DOS PROCESSOS VERBAIS DIZER/AFIRMAR, MOSTRAR/FALAR DE GRADUANDOS EM LETRAS}

A elaboração de um artigo acadêmico compreende etapas como leituras teóricas, coleta de dados, descrição e interpretação destes à luz de uma vertente teórica e, por fim, a própria escritura. Neste percurso, uma prática se apresenta como constitutiva do artigo e de outros gêneros da esfera científica: trata-se da citação, de modo direto ou indireto. Essa prática, quase que obrigatória, tem a função, dentre outras, de permitir que o escritor se respalde em outros autores para sumarização da teoria escolhida ou para sustentar seus argumentos, seja na discussão de conceitos, seja na interpretação dos resultados. Como autores de primeira viagem na seara acadêmica, os alunos da graduação em Letras, talvez mais do que outros autores ditos experientes, fazem uso das citações em seus artigos, 
como forma de dar credibilidade a seus dizeres e aos seus achados, conforme ilustramos com os exemplos e respectiva análise que apresentamos a seguir. Como já foi apontando, neste trabalho, analisamos quatro processos verbais (dizer, afirmar, mostrar e falar) - mais recorrentes nos corpora. Para que a participação de cada autor deste artigo esteja claramente especifica$\mathrm{da}$, optamos por apresentar as amostras identificando as que pertencem à pesquisa realizada na UFPE (Souza, 2011) e as que pertencem à pesquisa da UERN (Mendes, 2011).

\subsection{O "dizer" em artigos cientificos}

Em primeiro lugar, apresentamos a organização léxico-gramatical das orações que utilizamos como demonstração do processo verbal "dizer", descrevendo seus processos e participantes, nas amostras D1 a D4.

D.1. Kehdi (1999:50) diz que, por serem vocábulos recorrentes, as palavras derivadas por este processo podem ser integradas na composição ou na derivação. (Vol. I)

D.2. Elas representam o que foi denominado "heterogeneidade do discurso" (AuthierRévuz, 1982 apud Possenti, 1998:85), ou seja, pode-se dizer que "sob as palavras encontram-se outras palavras” (Starobinsky, 1971, apud Possenti, 1998). (Vol. I)

D.3. Diante disso, podemos dizer que os frames gerados a partir da variação lexical no gênero noticioso do telejornal e imprensa escrita podem manipular, criar e induzir construções mentais pré-determinadas pelos criadores do discurso, quer seja pelo gênero da notícia, pela característica idealista da emissora ou pelo locutor/escritor do texto. (Vol. I)

D.4. As estratégias de referenciação utilizadas pelos telejornais são semelhantes às estratégias utilizadas pela imprensa escrita, o que reforça a visão das características do uso da fala e da escrita pelo contínuo tipológico, e não como modalidades opostas, como já dissemos anteriormente. (Vol. I)

O processo verbal em uso nessas orações apresenta-se: de forma não modalizada em dois casos - D.1 e D.4; e modalizada nos exemplos D.2 e D.3. O participante Dizente realiza-se: em Grupo Nominal, caso - D.1; sob indeterminação do sujeito por meio do pronome se, em D.2; e marcados na morfologia do processo em dois casos, destes, a marcação desinencial 
acontece no processo poder que marca a modalização ${ }^{1}$. D.3; e outra no próprio processo verbal, D.4. O participante que codifica o dito realiza-se, nas orações recortadas, sob a forma de oração projetada a qual recebe o nome de Locução, ora projetando o discurso direto - D.2, ora o discurso indireto, casos D.1, D.3, D.4.

Passamos agora aos significados construídos pelas orações com o processo verbal "dizer" a partir das organizações léxico-gramaticais, descritas na introdução do tópico, em relação com a ambiência contextual na qual tais orações ocorrem. Em relação à modalização, nos casos ilustrados, podemos compreendê-la como uma atitude de precaução do autor para com o seu dizer, uma vez que ele o ancora em um dito imbuído de autoridade por materializar a voz de um autor renomado no tema em questão, como D.2, ou de um conjunto de elementos anteriormente apontados, como D.3, no qual o conjunto é retomado pelo demonstrativo "isso". Já a escolha do próprio processo verbal (dizer) sinaliza um desejo de materializar ditos oralizados, compreendendo, pois, a oralidade com o peso da tradição que essa possui em nossa cultura: ele disse, alguém disse, se diz, nós dissemos - se é assim, então é verdade. Dessa forma, a escolha desse processo verbal para introduzir as definições e argumentações pretendidas é reforço duplamente significativo, porque tem a força da oralidade e a força da escrita que, por sua vez, reverbera essa força da oralidade.

Ao que vamos chamar de "diversidade léxico-gramatical” de codificação do participante Dizente, podemos perceber, no exemplo D.1, pelo uso do grupo nominal - Kebdi - um recurso explícito do autor do artigo de buscar apoio teórico para sustentar seus argumentos. A indeterminação do Dizente - caso D.2 - parece-nos representar uma proteção autoral sob o uso da terceira pessoa do singular, tão defendida em tempos passados como mostra da pretendida imparcialidade do discurso acadêmico. A pronominalização na

1. Em virtude do considerável número de processo verbais acompanhados dos indicadores de modalidade, decidimos tratar, ainda que genericamente, desse componente da metafunção interpessoal da linguagem. A modalidade, conforme a explicam Fuzer e Cabral (2010), "é um recurso interpessoal utilizado para expressar significados relacionados ao julgamento do falante em diferentes graus. Refere-se a como os falantes e escritores assumem uma posição, expressam opinião ou ponto de vista ou fazem um julgamento". Esta noção se relaciona às proposições (modalização) e às propostas (modulação). A modalização pode ser expressa em graus de probabilidade ou usualidade e a modulação em graus de obrigação e inclinação. Detectando em significativa parcela de nosso dados, a modalização realizada pelo processo poder manifestando uma apreciação do autor, achamos por bem destacar a sua presença e comentar sua contribuição na construção do dizer aqui investigado. 
forma desinencial dos exemplos D.2 e D. 3 encapsula o autor e o dizer desse autor; é sua voz ocupando um espaço que lhe é natural enquanto criador dessa escrita acadêmica, ainda que o seu dizer seja construído amparado em vozes externas ao texto, como podemos ver nas orações projetadas que compõem a configuração oracional em sua completude. Podemos, então, compreender esta realização léxico-gramatical do Dizente como o espaço da manifestação do sujeito autor e apresentação de seus argumentos, de seu conhecimento adquirido.

As orações projetadas (chamadas de Locuções), seja sob a forma de discurso direto como em D.1, ou de discurso indireto, como em D.2, D.3, D.4, complementam a cadeia de "Participantes" do processo verbal em uso e materializam o dizer, ou seja constroem o dito, o comunicado, o apontado, seja para trazer uma voz de autoridade, como D.1 e D.2, seja para consolidar um pensamento do próprio autor, como D.3, D.4, movimento discursivo fundamental e, por isso, constitutivo, do discurso científico, seja no artigo acadêmico, objeto de nossa análise, seja em dissertações e teses, conforme comprovam nossas experiências de produtores e leitores desses gêneros. As Locuções ora analisadas localizam um dizer autoral, do escritor ou de uma referência na área, de presença incontestável na construção do texto acadêmico, sendo imprescindíveis à consolidação do pensamento que se expõe e defende.

As amostras que seguem, dos artigos dos anais de eventos científicos do CAMEAM/UERN, exemplificados em D.5 a D.8, reforçam alguns desses movimentos discursivos:

D.5. Podemos, de antemão, dizer que as reflexões e discussões atuais no campo visam priorizar um ensino mais voltado para a prática de atividades interativas de linguagem, vislumbrando momentos em que os sujeitos tenham a oportunidade de se expressarem diante das situações de comunicação. (Anais 1)

D.6. Ao serem perguntadas sobre suas formas de ensinar, as professoras dizem assumir uma postura construtivista em sala de aula, compreendendo a relação professor-aluno como algo dinâmico que permite uma interação entre o que precisa ser ensinado pelo professor e o que precisa ser aprendido pelo aluno quanto aos conteúdos trabalhados. (Anais 1)

D.7. Podemos dizer que a aprendizagem de uma língua se dá no desenvolvimento da competência no uso de várias funções da linguagem, ou seja, para compreendermos uma linguagem temos que entender as relações sociais que são manifestadas no cotidiano, as quais designamos de gêneros textuais. (Anais 1) 
D.8. Grosso modo, poderíamos dizer que a sintaxe é a organização funcional (frases, enunciados) de uma dada língua, enquanto que a semântica se preocuparia com o sentido e a referência destas frases e enunciados num dado contexto de uso da língua. (Anais 1)

Quanto à modalização, é possível indicar as amostras D.5, D.7 e D.8 como sendo modalizadas, restando D.6 como não modalizada. Nas mesmas amostras, o Dizente, enquanto participante obrigatório realiza-se nos três casos, por meio do pronome desinencial de primeira pessoa do plural. Em D.6, "as professoras" tipifica bem uma ocorrência de participante Dizente como grupo nominal explícito. Nas amostras dos anais de eventos, as Locuções estão presentes para projetar o discurso indireto.

A presença dos processos verbais demanda possibilidades significativas variadas, principalmente quando compreendemos que as escolhas configuradas no texto acadêmico mobilizam o desejo de uma "exposição/apresentação objetiva” acerca de um tema tido como objeto científico. Assim, os casos de modalização, a exemplo do que foi apontado na análise das amostras D.1 a D.4, da Revista Ao pé da letra, indicam frequentemente a necessidade de resguardar a posição do Dizente no texto científico (o leitor pode ver as amostras D.5, D.7 e D.8), de modo que suas proposições não demandam apenas de sua condição autoral, mas talvez da "veiculação" de um postulado comumente aceito pelo leitor/avaliador do trabalho acadêmico. O modo do processo no caso D.8 exemplifica ainda melhor essa posição, uma vez que estabelece hipótese para o "dizer" em "... poderíamos dizer que a sintaxe...", condicionando ainda mais a presença do autor no texto.

Embora nos trabalhos de Ao pé da letra tenhamos verificado a presença de voz do autor citado (discurso direto), nas amostras dos anais do CAMEAM/ UERN, os processos verbais, principalmente quando estão modalizados, sugerem um autor mais comprometido com a Verbiagem, porém mais precavido com o que é dito. O Dizente sob a forma desinencial, indicando a primeira pessoa do plural, é um indício claro desse zelo ou cuidado, num explícito atendimento às sugestões de modalização do discurso feitas muitas vezes pelos professores da academia, quando trabalham a produção textual científica.

É possível que essa condição de "poder dizer", como em D.8, reforce um papel de sujeito que não teria autoridade para fazer, sozinho, certas afirmações, ou para assumir tão prematuramente o ônus de certas posições 
científicas. Contrariamente, esse "poder dizer" talvez configure um recurso persuasivo nos moldes do conhecido plural de modéstia, em que o sujeito, sendo conhecedor do que diz, reveste-se de uma retórica que implica o convencimento sem parecer incisivo.

Em D.6, o processo verbal, como também vimos em D.2 e D.3, aponta para uma representação de ditos oralizados: quando o autor do artigo indica ter indagado os informantes de sua pesquisa e, na sequência, trazendo a resposta de sua questão acompanhada do processo "dizer", é possível verificar aí um interesse pela reprodução do que foi dito por outrem e esse dito não é apenas uma retomada do discurso, mas da própria voz do informante como condição e reforço para as premissas do escrevente do trabalho acadêmico-científico.

\subsection{O "afirmar" em artigos científicos}

Assim como fizemos em relação processo "dizer", tratamos nesta seção da organização léxico-gramatical das orações que utilizamos como demonstração do processo verbal "afirmar", descrevendo seus processos e participantes, nas amostras A.1 a A.4., do corpus constituído por artigos da revista Ao Pé da Letra:

A.1. Se nos fixarmos no significado dos componentes dessa última formação, poderemos afirmar que tal nome de fantasia insinua que a loja e seus consumidores estão "em pacto" um com o outro. (Vol. 1)

A.2. Isso nos leva a afirmar que mesmo sendo transmitido oralmente, o telejornal é um texto primariamente escrito. (Vol. 1)

A.3. É importante salientar ainda que estamos considerando o conceito de gênero segundo a classificação proposta por Marcuschi (1996:5) quando afirma que "o gênero textual é uma forma lingüisticamente realizada e encontrada nos diversos textos empíricos". (Vol. 1)

A.4. Assim, podemos afirmar que a metalinguagem, implícita ou explícita, é um recurso essencial na construção dos textos da imprensa. (Vol. 1)

O processo verbal "afirmar", em uso nessas orações, apresenta-se de forma não modalizada em dois casos - A.2 e A.3; e modalizada nos exemplos 
A.1 e A.4. O participante Dizente manifesta-se como Grupo Nominal em A.3; sob Grupo Pronominal em A.2; e marcados na morfologia do processo em dois casos, A.1 e A.4; em ambos, a marcação desinencial acontece no processo modalizador poder. O participante que codifica o dito, realiza-se sob a forma de grupo nominal - Verbiagem - ou em oração - Locução.

Em relação à modalização, em A.1 e A.4, há uma aparente intenção de apresentar o "afirmar" como uma sequência/conclusão possível. Quando os autores dos artigos modalizam o processo acabam por trazer para o leitor a ideia de que o seu discurso é verossímil em razão do que foi dito anteriormente. Ora, em A.1, a Locução que estabelece condição é complementada não por uma hipótese, mas pelo motivo do afirmar (Se x, poderemos afirmar...). Nesse caso, a indicação no tempo futuro também retoma a ideia de conclusão possível, como já sugerimos. Por meio da modalização em A.4, o processo se apresenta na sequência de um marcador conclusivo, ou seja, o "afirmar", nesse caso, é uma condição sine qua non da organização discursiva, e a modalização se volta muito mais para os moldes da argumentação do que para a necessidade de resguardar a posição do Dizente no texto científico, conforme observamos no processo "dizer". O mesmo pode ser compreendido deste caso não modalizado: "Isso nos leva a afirmar que...", em A.2. Em outras palavras, quando o autor emprega esse processo pode estar sugerindo que a Verbiagem/Locução é uma conclusão que se ajusta a uma premissa retomada do texto: a) Se x, poderemos afirmar; b) Assim, podemos afirmar; c) Isso nos leva a afirmar; etc.

A amostra A.3 amplia esse entendimento, tendo em vista que apresenta o processo associado a uma circunstância temporal, cujo Dizente está sendo retomado por processo de elipse (quando $\varnothing$ afirma). $O$ uso do afirmar aqui se apresenta para reforço das proposições com amparado de vozes externas ao texto, que permitem maior "segurança" ao que está sendo tratado. Essa configuração se assemelha ao que observamos anteriormente com o processo "dizer" e aponta para uma característica mais comum em diferentes processos verbais.

O participante Verbiagem ou as Locuções são encerrados com um caráter de "tese" ou indicação da presença do participante Dizente que, nesses casos, sente-se mais habilitado a demarcar certas posições. Como o uso de "afirmar" remete mais ao significado positivo de verdade e menos 
à oralidade (como é o caso de "dizer"), a presença nos textos acadêmicos permite compreender que o autor está mais convicto de suas proposições.

Nesse ponto, esclarecemos que a análise desses processos, nas amostras aqui trazidas, não encerra o assunto acerca de como o "afirmar/dizer" se apresentam em textos científicos. Na verdade, os casos destacados no corpus dos artigos de anais de eventos do CAMEAM/UERN, como veremos a seguir, admitem uma configuração diferente da que identificamos até então. E, se em apenas dois corpora diferentes já identificamos realizações diversas, é possível que haja outras formas de materialização de tais processos nos mais variados contextos de uso.

A descrição da organização léxico-gramatical das amostras do processo verbal "afirmar", em artigos de anais de eventos do CAMEAM/UERN, apresentados em A.5 a A8, mostra uma configuração menos coincidente com aqueles que foram apresentados da revista Ao pé da letra.

A.5. Esse autor afirma que é possível examinar a relação pedagógica a partir de três dimensões, as quais recobrem aspectos distintos e bastante amplos da questão: a linguística, a pessoal e a cognitiva. (Anais 1)

A.6. Porém, quando indagadas sobre qual(ais) concepção(ções) de linguagem melhor caracterizam as suas aulas, as professoras afirmam não ter conhecimento destas concepções, mas deixam claro que procuram trabalhar no dia-a-dia a partir de uma linguagem acessível, evitando usar termos ou palavras que sejam de difícil compreensão pelos alunos. (Anais 1)

A.7. Sobre esse assunto Widdowson (1991, p.15) afirma que: "A aprendizagem de uma língua abrange, portanto, a aquisição da capacidade de compor frases corretas. Esse é um dos aspectos da questão. Mas ele também inclui a aquisição de compreensão de como essas frases, ou partes delas, são apropriadas num contexto específico". (Anais 1)

A.8. Na quarta questão ele afirma que a sua prática de ensino se baseia na abordagem comunicativa, a qual ele defende, enquanto que, logo acima, na sua afirmação para a terceira questão, ele procura trabalhar a abordagem comunicativa sem descartar as demais. (Anais 1)

Nas quatro amostras, o processo não se apresenta modalizado, tendo em conta que seu uso faz referência a um participante Dizente de terceira pessoa do discurso, ou seja, o Dizente manifesta-se em Grupo Nominal em A.7, e sob Grupo Pronominal em A.5, A.6 e A.8. Em todos os casos, 
esse participante encontra-se marcado morfologicamente. A Locução, nesse caso, é sempre o discurso de um outro, podendo ser direto, como em A.7, ou indireto, como em A.5, A.6 e A.8.

As quatro amostras do corpus de artigos de anais de eventos apresentam uma realização mais recorrente: o processo verbal "afirmar" indica marca da introdução do discurso direto/indireto no texto. Excetuando A.7, as demais ocorrências se realizam para apontar a voz do outro, parafraseada pelo autor do trabalho científico. A não modalização do processo ainda reforça o caráter de pretensa objetividade na apresentação da Locução, de modo a explicitar um dito por outrem e não propriamente pelo autor do artigo. Em A.6 e A.8, o participante Dizente é reconhecido como o sujeito informante das pesquisas e o emprego do processo "afirmar" é usado, portanto, para demarcar esse papel. Essas escolhas ainda podem sugerir que os informantes foram inqueridos por questionário impresso e não por entrevista na modalidade oral, já que nesses casos observamos a presença do processo "dizer".

$\mathrm{Na}$ amostra A.7, temos um comportamento mais típico dos processos verbais: reforçar as teses por meio do discurso direto, ou melhor, da recorrência a uma voz de autoridade, capaz de conferir ao discurso um caráter mais persuasivo. Quando sugerimos que essa configuração é mais comum nos processos em questão, estamos indicando que "afirmar" e "dizer", por exemplo, podem marcar um envolvimento do autor do texto com suas teses, mas também o interesse pelo argumento de autoridade quer seja de um teórico, quer seja de um informante da pesquisa. E, embora em A.7 tenhamos a explícita introdução de discurso direto, já que o processo aponta para a citação de uma obra, nos demais casos o discurso indireto é ainda muito revestido da voz do outro, levando em conta que a paráfrase, por vezes, parece apenas acontecer pelas mudanças pronominais. Em outras palavras, a fronteira que o afirmar estabelece entre discurso direto versus discurso indireto pode, em certos casos, parecer bastante tênue.

\subsection{0 "mostrar" em artigos científicos}

Passamos agora a análise do terceiro processo verbal mais frequente nos corpora. A exemplo das seções anteriores, as quatro primeiras amostras são dos artigos da revista Ao Pé da Letra. O processo mostrar tem compor- 
tamento bem diferente dos demais processos, especialmente no que diz respeito à caracterização do Dizente:

M.1. Por outro lado, há no texto referentes que são retomados poucas vezes. É o caso de Rio de Janeiro, que é retomado por repetição; o sinônimo os fugitivos, que retoma quatro em "pelo menos outros quatro estão foragidos". O exemplo mostra que a notícia de jornal impresso varia na escolha das duas estratégias referenciais. Percebemos que essa escolha está estreitamente ligada ao grau de relevância do tópico, ou seja, na notícia, o mais importante são os atores e a ação. (Vol.1)

M.2. Isso faz com que ocorram as hesitações, os falsos inícios e as sobreposições de construção, em diferentes gêneros discursivos. O nosso estudo mostra que as sobreposições de construção ocorrem nos três gêneros de discurso estudado -diálogos entre dois informantes, diálogos entre informante e documentador, aulas e conferênciaspodendo ser consideradas como fazendo parte do próprio funcionamento... (Vol. 1)

M.3. Marcuschi (1999a) propõe um "quadro de relações anafóricas”, no qual se descrevem sete processos gerais de relações anafóricas e os seus esquemas categoriais. $\mathrm{O}$ autor mostra de que maneira essas relações anafóricas se dão na combinação dos três fatores intervenientes, isto é: +/- correferência, +/- recategorização, +/- cosignificação. (Vol. 2)

M.4. M.4. A escola, em sua relação com o Estado, e o Discurso Pedagógico que aí se produz, são elementos constituintes e constitutivos da(s) ideologia(s) dominante(s). Althusser (1980) mostra que a escola substituiu, a partir do século XIX, competentemente, a igreja como "aparelho ideológico de Estado número um". (Vol. 2)

Nas ocorrências apresentadas, o processo não apresenta qualquer tipo de modalização, considerando-se que o participante Dizente é de terceira pessoa discursiva. A moldura semântica de "mostrar" é que parece variar em conformidade com a Verbiagem, como se pode notar quando comparamos, por exemplo, M.2 e M.3: no primeiro caso, o participante Verbiagem funciona como proposição e, no segundo, a Verbiagem indica procedimento, o que nos permite indicar que, em certos casos, o processo em questão está mais para verbal e em outros mais para as fronteiras com os demais tipos.

Sobre o Dizente ainda cumpre observar que, nas quatro amostras, encontra-se marcado morfologicamente, a saber: grupos nominais que introduzem referente novo ao discurso, como em M.2 e M.4, ou que se propõem à retomada de sentidos já apresentados em M.1 e M.3. A escolha pelo processo "mostrar" nos textos dos acadêmicos parece apontar para uma 
necessidade de introduzir o discurso do outro, de forma indireta, porém, com um caráter mais persuasivo: mostrar, nesse caso, é mais do que simplesmente "dizer" ou "afirmar" porque talvez implique "provar".

A exemplo do que analisamos em outros processos, a não modalização do processo ainda reforça o caráter de pretensa objetividade na apresentação dos dois participantes obrigatórios: o primeiro (Dizente), porque tem autoridade para mostrar efetivamente o que vai ser proposto no segundo (Verbiagem/Locução), que enuncia algo crível porque teoricamente está para além de afirmar/dizer. Vejamos que as duas últimas ocorrências, que apontam Marcuschi em M.3 e Althusser em M.4 como Dizentes, apresentam por força das demais escolhas operadas no plano da Verbiagem um modelo de valoração ao que está sendo trazido para o discurso, a saber: as circunstâncias de tempo e de modo, respectivamente indicadas na Locução em M.4.

O mesmo pode ser analisado das amostras seguintes, do corpus constituído por anais de eventos, em que os participantes se realizam basicamente da mesma forma como nas quatro ocorrências anteriores:

M.5. Para ensinar LI é fundamental que o professor desta disciplina tenha uma concepção nítida do que seja linguagem, pois somente assim ele desempenhará melhor a sua prática pedagógica. A esse respeito os PCNs (1997, p.9) mostram que: "Ao ensinar uma Língua Estrangeira, é essencial uma compreensão teórica do que é a linguagem, tanto do ponto de vista dos conhecimentos que as pessoas necessitam para usá-la, quanto em relação ao uso que fazem destes conhecimentos para construir significados no mundo social." (Anais I)

M.6. Esse tipo de leitura enfatiza o método mecanicista, em que o aluno é levado a completar sentenças, repetindo palavra e frases já existentes no texto. Ao lado disso, Kleiman (2008) mostra que, além da decodificação, muitas vezes a leitura é levada apenas a repetir o que o autor do texto diz, o que dispensa a etapa da compreensão dessa voz e não oportuniza solicitar uma opinião dos alunos sobre um assunto que, por ora, realizou-se a "leitura" do texto, sem sequer ter discutido o assunto tal qual ele é tratado pelo autor. (Anais I)

M.7. É importante considerar o conhecimento prévio que a criança possui, inferindo sobre o que um determinado texto quer transmitir. Ora, a criança, em sua fase de aquisição da linguagem, assim como mostra Scarpa (2001, p. 118), é dada através do sociointeracionismo, em que a linguagem e conhecimento do mundo estão inteiramente relacionados e os dois passam pela medição do outro, do interlocutor. (Anais I) 
M.8. Ainda sobre os gêneros, Rodrigues (2005, p. 163) nos mostra a concepção de Bakhtin, onde este opta pelo termo gênero do discurso, definindo-os como tipos relativamente estáveis de enunciados ou formas relativamente estáveis e normativas de enunciados. (Anais I)

Em M.5 o processo introduz o discurso direto: o participante Dizente, que é o documento ministerial que apresenta propostas para o ensino na Educação Básica, legitima a tese de que ao docente de língua inglesa cumpre "ter uma concepção nítida do que seja linguagem", concepção esta que vai ser "mostrada" na Locução, quando o autor do artigo recorta a citação dos PCNs.

Quanto ao interesse de dar contorno ao que está sendo dito, o autor do texto, por vezes, traz a voz do outro de forma indireta, como em M.7, quando o Dizente associado ao processo parece ser um "reforço" à ideia proposta, sobretudo pelo fato de se ter estabelecido uma relação comparativa entre o que propõe o autor do texto e o que pode ser "mostrado" pelo teórico citado. Situação semelhante é o que ocorre em M.6, quando o participante Dizente foi antecedido por um conector que estabelece comparação com o trecho anterior.

A primeira ocorrência do participante Receptor pode ser observada em M.8, realizado pelo pronome "nos". Como este participante é menos obrigatório na proposta do Sistema de Transitividade de Halliday, a sua ocorrência é pouco efetiva. O graduando inclui-se nesse aspecto de recepção, indicando que, além do leitor, ele compartilha da "tese" proposta pelo autor citado, o que ratifica a necessidade de adesão do outro e, ao mesmo tempo, sugere que as escolhas operadas no plano da léxico-gramática não poderiam por nenhuma força ser resultado movimentos aleatórios.

Se compararmos o processo "mostrar" aos que já foram analisados até então, vamos perceber claramente que ele se apresenta com certa uniformidade do ponto de vista da materialidade textual e da função semânticodiscursiva. Mais do que isso, o uso desse processo denota a necessidade que o escritor menos afeito à produção textual na academia tem de valorizar as informações introduzidas e de conferir-lhes uma proposição mais objetiva ou menos passível de levantar questionamentos pelo leitor. 


\subsection{O "falar" em artigos cientificos}

O processo menos recorrente nos corpora, entre os que foram analisados neste artigo, foi "falar". O discurso introduzido por este processo se assemelha, no plano da realização e das escolhas léxico-gramaticais, aos dois analisados no início (dizer e afirmar). Vejamos exemplos de artigos da revista ao Pé da Letra:

F.1. Desta forma, a especificidade da forma literária, pautada na perspectiva dialógica, concebe que a dialogicidade interna do discurso, tal qual fala Bakhtin, não comporta elementos externos de "composição", não pode pretender ascender a uma dada realidade e empregar elementos alheios a esta situação, pois não pode existir de forma dissociada... (Vol. 3.1)

F.2...em que os interlocutores interagem em atividades coordenadas e colaborativas de co-produção de sentidos. Podemos falar ainda sobre as expectativas prévias que os interlocutores criam nas situações interacionais. De acordo com Dionisio (2001: 94) "em situações interativas, os interlocutores sempre têm expectativas prévias"... (Vol. 3.2)

F.3. A respeito da identidade de gênero, Crawford (1995: 4) aponta que o significado da diferença de sexos é produto da negociação social, i.e., é produzido culturalmente. Nesse sentido, ao falarmos do traço social de gênero, devemos ter em mente que seus significados são socialmente construídos, ao contrário do sexo que nos é atribuído, pois esse é biologicamente determinado. (Vol. 4.1)

F.4. Cito novamente Octavio Paz - sempre bem-vindo - com sua feliz explicação dessa eterna busca da nossa cara/máscara-metade que nos move dia a dia. Teorizando poeticamente, Paz nos fala da diferença entre amor e erotismo e do processo simbiótico que se dá entre esses dois sentimentos para que uma vã sensação de plenitude nos sacie: "O amor é atração por uma única pessoa: por um corpo e uma alma. (Vol. 4.1)

As amostras do processo em análise, com exceção da primeira, apontam para envolvimento do participante que "fala". É possível que esse envolvimento decorra de motivações específicas do gênero artigo (a exemplo de outros do domínio acadêmico), como a recorrência à voz de autoridade de teóricos/analistas. Necessário se faz acrescentar que o processo em questão remete mais à realização oral e menos à escrita, tendo em vista que "falar" apresenta uma significação que demanda a emissão da voz. Em outras palavras, o uso desse processo pelos alunos graduandos permite compreender 
que, em função de serem ainda autores iniciante, com menos contato com o gênero e, portanto, menos "afeitos" ao repertório disponível para indicar o discurso citado, a escolha de "falar" pode resultar do contato com outros textos e/ou com outras condições de interação em que os processos que denotam narração, reprodução da fala de personagens etc. são mais comuns.

Em F.1 o processo associado ao participante Dizente (Bakhtin) conduz o leitor para a compreensão de que a Locução - apresentada logo no tópico da oração - é a ideia que o autor do artigo se propõe a defender. A tese, porém, respaldada na "fala" de um filósofo representativo, em quem o escritor do texto encontra apoio, ganha um caráter verossímil em função dos termos que estabelecem relação entre as orações (tal qual) e em razão da atualidade do processo ("falar" se realiza no momento presente). Assim, a "fala" de Bakhtin, tal qual a afirmação (Locução) feita pelo aluno-autor, deveria ser tratada como mais relevante pelo leitor porque se encontra associada à proposição feita. Quando o escrevente do texto optou por dispor o Dizente e a Locução com a configuração que estamos observando, houve, de certo modo, uma maior valoração de sua própria afirmação - que, evidentemente, encontra a ancoragem necessária no participante Dizente. A posição que ocupou o processo (depois da oração tópica) aponta, portanto, para a compreensão de que: primeiro, embora a proposição do autor do texto não seja propriamente sua, mas do participante que "fala" (nesse caso, Bakhtin), a realização léxico-gramatical presente em F.1 pode sugerir, ao leitor, certa "autonomia teórica" da parte do escrevente, talvez pela introdução indireta do discurso; segundo, a comparação realizada por "tal qual" reforça o caráter de objetividade que o autor pretende para sua tese; e, por último, a escolha de "falar" contribuiu para o envolvimento efetivo do participante Dizente em relação ao que é dito.

O contrário disso se verifica em F.4, quando o participante Dizente é dado como responsável direto pelo que está sendo proposto pelo autor do texto. Nessa amostra, a presença do participante Receptor "nos" (primeira pessoa discursiva) indica, numa realização inversa àquela presente em F.1, a valoração que é dada à "fala" de autoria citada (Paz). Essa participação mínima pode refletir, da parte de quem escreve, uma maior necessidade de preservação de face ou mesmo certa dificuldade de parafrasear, ampliar o que é dito, como também, de manter o objetivo predominante, quando do emprego dos processos verbais em artigos acadêmicos, que é o de trazer o 
discurso do outro como forma de "certificar" as questões que estão sendo lançadas no texto.

A segunda e terceira amostras apontam para essa finalidade mais frequente nos processos do dizer. Em contrapartida, é necessário observar que nas ocorrências F.2 e F.3 a Verbiagem não é um discurso citado. Ou seja, o envolvimento do Dizente, nos acasos apontados, apela para duas condições possíveis de realização: o participante que "fala" assume o ônus do que é dito; ou, o que está sendo "falado" simplesmente é reiteração ou proposição de ideias que têm como base a citação feita antes, como em F.3, ou depois, como em F.2.

As ocorrências no corpus dos artigos de congressos apresentam configuração semelhante aos analisados até então, especialmente no que diz respeito à introdução do discurso citado, com participante Receptor:

F.5. Quando se fala em Dialogismo, remete-se "ao modo de funcionamento real da linguagem" (Fiorin, 2006, p. 82), através do qual um enunciado ou discurso sempre se constrói em relação a outros. (Anais I)

F.6. Não se pode deixar de falar da possibilidade dos discursos produzidos pelos sujeitos, em diferentes condições de produção, dialogar com outros discursos, a partir da retomada de formulações anteriores. (Anais I)

F.7. Nesta obra, Nísia argumenta na tentativa de comprovar a veracidade de suas afirmações sobre a importância de uma educação feminina mais igualitária. Ela fala sobre vários momentos da condição feminina no decorrer da história e mostra exemplos claros de nações consideradas progressistas para o desenvolvimento desta temática. (Anais I)

F.8. Vale salientar que neste trabalho trataremos a poesia de cordel produzida pelo poeta cearense Patativa do Assaré que inicialmente foi publicada em folhetos e hoje está reunida em antologias. Para um maior esclarecimento, Maria Ignez Ayala nos fala que: Outro fator que contribui para a identificação de folheto com o repente é a base oral desta poesia escrita. Sabe-se que muitos poemas da literatura de folhetos são construídos a partir de temas de narrativas populares orais. Além disso, a métrica, os esquemas rítmicos e os tipos de estrofes (sextilha, septilhas, décimas, entre outros) utilizadas nos folhetos também são encontrados nos repentes. [...] (Anais I)

A última amostra se realiza de modo semelhante à F.4, em que o participante Dizente é introduzido como responsável direto pelo que está sendo "dito", e o Receptor "nos" mobiliza da parte do leitor mais atenção 
à tese corroborada pelo autor que é apresentado sob a forma de citação. Ocorrência comum é também a que podemos identificar em F.7, quando o processo "falar" tem um participante Dizente (em terceira pessoa) que recupera o autor citado por mecanismo de reiteração.

Destas últimas quatro amostras, F.5 e F.6 é que apresentam realização léxico-gramatical do processo "falar" com impessoalidade no discurso - aliás, são as únicas ocorrências entre as que foram apresentadas neste trabalho. Essa frequência em menor número sugere que a realização do Dizente com a marca do processo em terceira pessoa + "se" demonstra distanciamento e/ou menor envolvimento do escrevente com aquilo que é dito. Mais do que isso, pode haver também a pretensa condição de objetividade do "cientista" que deve, nos estatutos mais positivistas, manter-se distante e não diretamente envolvido com o objeto ou com as teses da pesquisa.

Os casos aqui demonstrados, assim como os demais averiguados para a consecução da pesquisa sintetizada neste artigo, ratificam a hipótese de que os processos verbais introduzem opiniões, argumentos, definições, classificações, com maior/menor envolvimento do autor, o que demonstra a potencialidade argumentativa desses processos e dos participantes a eles associados na tessitura do gênero artigo acadêmico de graduandos, em especial dos graduandos em Letras - como é o caso dos corpora analisados.

\section{Conclusão}

A título de conclusão, podemos dizer ou afirmar que o uso dos processos verbais está ligado ao teor argumentativo do gênero artigo acadêmico/ científico, no sentido de que as vozes presentes nesse processo de construção de sentidos vêm funcionar como argumentos de autoridade e não apenas como sequências dialógicas, função que ocupam os processos verbais no caso das narrativas orais, ou relatos, diálogos - função preenchida também nas narrativas escritas.

Os dados ainda nos permitem compreender, de modo mais específico, que o processo "dizer" propicia uma atitude de precaução do autor para com suas teses. Assim, os participantes Verbiagem e Dizente, respectivamente, prestam-se a localizar um dizer autoral, sendo imprescindível à consolidação do pensamento que se expõe e defende, e a buscar apoio teórico para sustentar seus argumentos. 
Em relação à modalização, nas amostras do processo "afirmar", há uma aparente intenção de apresentá-lo como responsável por introduzir uma sequência/conclusão possível, já que algumas vezes o participante Verbiagem apresenta esse caráter de consequência projetada. Porém, é importante registrar que o processo "afirmar" apresenta configuração também bastante recorrente: marcar a introdução do discurso direto/indireto no texto, não apenas como sequência de vozes, mas como procedimento argumentativo.

O processo verbal "mostrar" apresenta certa uniformidade, do ponto de vista da realização léxico-gramatical e da função semântico-discursiva. Nos casos evidenciados, esse processo sugere a valorização das informações apresentadas - que não são simplesmente ditas, mas também "mostradas". Do processo "falar", é possível dizer que seu uso contribuiu para o envolvimento efetivo do participante Dizente em relação ao que é dito, quando este participa diretamente sob a forma de discurso em primeira pessoa; ou para o distanciamento do escrevente, quando o participante Dizente se realiza no modo impessoal (processo + se).

Portanto, a presença dos processos verbais demanda possibilidades significativas variadas, inclusive quando compreendemos que as escolhas configuradas no texto acadêmico trazem ainda uma pretensa necessidade exposição objetiva da realidade analisada. Quando indicamos ser pretenciosa tal condição, estamos falando ou mostrando não ser possível a investigação/ descrição de um fenômeno, com procedimentos científicos, sem que isso implique um sujeito envolvido, capaz de operar num plano de diferentes escolhas e usos, e consciente ou não de seus interesses e das possibilidades que os processos verbais desempenham em contextos argumentativos, já que podem reforçar o caráter de verdade, tido como típico da pesquisa acadêmico-científica.

Recebido em setembro de 2011 Aprovado em dezembro de 2011 E-mails: medianeirasouza@yahoo.com.br wellingtonmendes@uern.br

\section{REFERÊNCIAS BIBLIOGRÁFICAS}

Barbara, L.; Macêdo, M. C. M. de. 2011. Processos verbais em artigos acadêmicos: padrões de realização da mensagem. In: BARBARA, L.; 
Moyano, E. Textos y lenguaje académico: exploraciones sistémico-funcionales en portugés y español. Los Polvorines: Universidad Nacional de General Sarmiento; Pontificia Universidad Católica de São Paulo, p. 221240.

Furtado da Cunha, M. A.; Souza, M. M. de. 2011. Transitividade e seus

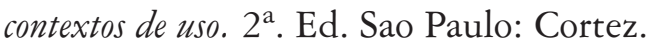

Fuzer, C.; Cabral, S. R. S. (orgs.). 2010. Introdução à gramática sistêmicofuncional em língua portuguesa. Santa Maria: UFSM.

GHIO, E.; FernANDEZ, M. D. 2008. Lingusitica sistémico-funcional: aplicaciones a la lengua espanola. Santa Nacional del Litoral/Wadhuter Editores.

Halliday, M. A. K. 1985. An Introduction to Functional Grammar. London: Edward Arnold.

Halliday, M. A. K.; Matthiessen, C. M .I. M. 2004. Introducion to Functional Grammar. London: Arnold, third edition.

Halliday, M. A. K.; Matthiessen, C. M .I. M. 1999. Construing experience through meaning: a Language-based Approach to Cognition. London/New York: Continuum Publishing Group.

Hoffnagel, J. C. 2009. A prática de citação em trabalhos acadêmicos. In: Cadernos de Linguagem e Sociedade. Vol. 10.1, p. 71-88.

Matthiessen, C. M .I. M; Teruya, K.; Lam, M. 2010. Key terms in systemic functional linguistics. London/New York: Continuum Publishing Group.

Mendes, W. V. 2011. Corpus da pesquisa os processos do dizer na produção científica dos graduandos em letras do CAMEAM. Pau dos Ferros: Faculdade de Letras e Artes/UERN. (Arquivo eletrônico).

Sardinha, T. B. 2009. Pesquisa em linguística de corpus com Wordsmith Tools. São Paulo: Mercado de Letras.

SouzA, M. M. 2011. Corpus da pesquisa o funcionamento dos processos verbais em artigos acadêmicos. Recife: Faculdade de Letras/UFPE. (Arquivo eletrônico).

SouzA, M. M. de. 2006. Transitividade e construção de sentido no gênero editorial. Tese de doutorado. Recife: UFPE. 